logist for the more accurate observation of the different subjects under identical climatic conditions. H. Fairfield Smith, of the Galton Laboratory, University College, London, also makes his report of the preliminary statistical investigation of the flowering dates of plant records in the Phenological Reports of the Royal Meteorological Society (Quart. J. Roy. Met. Soc., Jan. 1938) showing the standard deviations in restricted localities appear to be about 5-7 days for late spring and summer plants, rising to 13 days for early spring and autumn flowering plants. The country-wise standard deviation of locality means for hazel and hawthorn in 1933 was about 4-5 days, and regression of flowering date on altitude about $1 \cdot 3$ days per 100 feet. Temperature appears to be the dominating meteorological factor determining flower dates, which vary within a locality as a function of climatic as well as of individual plant and environmental factors.

\section{Smithsonian Archæological Expeditions}

Two expeditions of the Smithsonian Institution of Washington, it is announced, have taken the field for the operations of 1938. Dr. F. H. H. Roberts, jun., has left for the Lindenmeier site in northern Colorado, where he will continue his work of excavation on the camp site once occupied by Folsom man; and Dr. Aleš Hrdlička is on his way to the Aleutian Islands, where he will carry further the archæological and ethnological investigations on which he has been engaged on behalf of the Smithsonian Institution in each year since 1926, with the object of determining the character and course of the early migrations of man to the American continent. It will be remembered that Dr. Hrdlička, after devoting several seasons to the Eskimo problem, and the succession of cultures in the far north, has in his recent expeditions turned to the Aleutian islands, which he regards as one of the original migration pathways into North America. Here he has found in the eraniological material excavated evidence of two distinct types of man, of which the later is distinguished from the earlier by an increase in the breadth of the skull, just as he had found two forms of Eskimo skull, also differentiated by an increase in breadth in the later type. The evidence as a whole, he maintains, points to the fact that all this northwestern region of the continent was a "nursery of peoples", constituted by several related strains of Asiatics, from which either the pronounced Eskimo or the typical Indian could easily have developed.

DR. RoBerts's problem is also concerned ultimately with the question of the character of early man in North America, for one of the main objectives of the fourth season's excavation on the Lindenmeier site will be an intensive search for the skeletal remains of Folsom man, of which no trace has as yet been found on any of the several sites which have been investigated by various explorers. Further, a change in orientation in the study of the Folsom culture may be necessary. Hitherto it has been accepted that Folsom man followed the bison which" in turn, followed the retreating glaciers northward to take advantage of the pasture which sprung up behind the melting ice. The recent discovery of what are believed to be relics of the Folsom hunters so far north as Saskatchewan, and of the same date as the Colorado culture, is difficult to reconcile with the hypothesis most generally held that at this period the region in which these northern relics have been found was covered with glacial ice some hundreds of feet thick. This discovery would appear to lend support to the theory of some geologists that an ice-free corridor extended from Alaska southward, in which vegetation was probably dense, and in which men and animals migrated freely.

\section{Studies of the Later Iron Age}

Authougr it is a commonplace that archæology is a 'young' science, this can be appreciated in its fullest implication only when a comprehensive survey is made of some one department of archæological studies such as that of the La Tène culture in Mr. J. M. de Navarro's Sir John Rhys Memorial Lecture for 1936 before the British Academy ("A Survey of Research on an Early Phase of Celtic Culture", Humphrey Milford, pp. 42, 1937. 3s. net). The La Tène culture, especially in its artistic manifestations, has so high a place in the development of protohistoric studies, and has been the subject of so much detailed investigation, which is recorded in a considerable literature, that it is difficult to realize that La Tène, the later of the two type stations or rather sites which have given their names to the principal divisions now recognized in the Iron Age, was first investigated so recently as 1856 , though sites and objects now regarded as belonging to that civilization were being discovered for some years before.

The credit of recognition of the full significance of La Tène belongs to Sir A. Wollaston Franks, whose contribution to John Kemble's "Horae Ferales" (1863), discussing a series of La Tène objects, was the first to envisage the ethnical aspect of that civilization in its true light, although Thurnham in "Crania Britannica" (1857) had already grouped together certain La Tène metal types as 'Late British' and assigned them to a bronze and iron transition period. It was, however, Franks who first recognized the geographical extension of the La Tène culture and identified it with the Celts. Among later contributors to the archæological aspect of Celtic studies, to whom Mr. de Navarro refers, three names stand out-Sir Arthur Evans, for the account of his excavation of the LateCeltic urnfield at Aylesford, Kent (1890), and Paul Reinecke, to whom is due the first comprehensive survey of La Tène culture (1902); but in the remarkable recent development of archæological study of the later Iron Age, of which Mr. de Navarro takes account, the influence is pre-eminent of J. Déchelette, whose "Manuel d'Archéologie Celtique" appeared in 1914, and whose untimely death in the Great War is still mourned as one of archæology's gravest losses in that struggle. 